\title{
ERRATUM
}

\section{Effects of tropical deforestation on climate and agriculture}

Deborah Lawrence and Karen Vandecar

Nature Climate Change 5, 27-36; 2015; published 18 December 2014; corrected after print 18 December 2014.

In the print version of this Review, the 'published online' date should read 18 December 2014. The online versions are correct. 